Original Paper http://ajol.info/index.php/ijbes http://indexmedicus.afro.who.int

\title{
Microbial production of 2,3-butanediol from rice husk using anaerobic Clostridium species
}

\author{
A. SANUSI ${ }^{1 *}$, A. A. FAROUQ ${ }^{2}$, A. Y. BAZATA ${ }^{3}$, A. D. IBRAHIM ${ }^{2}$, I. \\ MAS'UD $^{4}$, A. Y. BELLO ${ }^{5}$ and M. H. USMAN ${ }^{6}$ \\ ${ }^{1}$ Department of Microbiology, Kebbi State University of Science and Technology Aliero, Nigeria. \\ ${ }^{2}$ Departmentof Microbiology, Usmanu Danfodiyo University Sokoto, Nigeria. \\ ${ }^{3}$ Departmentof Microbiology, Federal University Birnin Kebbi, Nigeria. \\ ${ }^{4}$ Euro Mega Atlantic Nigeria Limited, Nigeria. \\ ${ }^{5}$ Department of Basic Science and General Studies, Federal Collage of Forestry Mechanization Afaka, \\ Kaduna, Nigeria. \\ ${ }^{6}$ Department of Microbiology, Sokoto State University, Nigeria. \\ *Corresponding author; E-mail: sanusiabubakar234@gmail.com
}

Received: 29-09-2020

Accepted: 05-01-2021

Published: 28- 02- 2021

\begin{abstract}
Interest in the area of biomass based-product production is increasing all over the world due to the environmental challenges posed by fossil fuel and fear of its extinction. Production of biofuel and other compounds especially from agricultural waste can reduce these environmental problems because of its sustainability and environmentally friendliness. One of the major petrochemical product widely used in many industries is 2,3-butanediol and was found to be produced from agricultural wastes by microorganisms. Therefore, Microbial production of 2,3-butanediol from rice husk using Clostridium species was investigated in this research. Structural composition of the rice husk was determined before and after pretreatment. Hemicellulose and lignin content of rice husk was determined after extraction while cellulose was determined as the difference from the extractives, hemicelluloses and lignin. Dilute $(2 \%) \mathrm{NaOH}$ was used for the pretreatment of rice husk. Hydrolysis was carried out using Aspergillus niger and reducing sugar released was determined using standard method with UV-VIS spectrophotometer. Clostridium species was isolated from sugarcane bagasse, identified using basic morphological and molecular biology techniques. The fermentation of rice husk was performed using the Clostridium species. Fermentation by-product was determined using Gas Chromatography Mass-spectrometry. Cellulose content increased from $32 \%$ before pretreatment to $53.3 \%$ after pretreatment, lignin increased from $8.4 \%$ before pretreatment to $30.7 \%$ after pretreatmemt and hemicellulose decreased from $30 \%$ before pretreatment to $8 \%$ after pretreatment. A total of $1.05 \mathrm{~g} / \mathrm{l}$ of reducing sugar was released after enzymatic hydrolysis of the rice husk with Aspergillus niger. Alcohol 2,3-butanediol $(0.6 \%)$ and Furfuryl alcohol $(0.45 \%)$ were detected in the by-product of fermentation. Other compounds detected are fatty acids that ranges from $C_{16}$ to $C_{25}$ with 9,12-Octadecanoic acid as the major fatty acid. From the results of this work, Rice husk was found to have substantial amount of sugar (cellulose and hemicelluce) that can be converted to valuable product including 2,3-butanediol.
\end{abstract}

(C) 2020 International Formulae Group. All rights reserved.

Keywords: Biofuel, Bio-refinary, Cellulose, Clostrudium, fermentation. 


\section{INTRODUCTION}

Development of bio-refinery system that integrates biomass conversion process and equipment to produce fuels and chemicals is a worldwide phenomenon due to the experiencing scarcity of crude oil reserves (Ragauskas et al., 2006). In view of this, many chemicals that are produced only from chemical processes can now be generated using biological means from renewable resources; in which microbial production of 2,3-butanediol is the typical example (Hatti-Kaul et al., 2007). There is remarkable interest in this bioprocess, because 2,3-buatnediol has diverse industrial applications, and microbial production will relatively reduce the current dependence on oil supply for the production of valuable chemicals (Celinska and Grajek, 2009; Wu et al., 2008).

Some potential applications of 2,3butanediol include manufacture of printing inks, perfumes, fumigants, moistening and softening agents, explosives, plasticizers, foods, and pharmaceuticals (Koutinas et al., 2014; Ji et al., 2011; Syu, 2001). It can also be used as a precursor in the production of other chemical products, such as solvents methyl ethyl ketone (MEK), gamma-butyrolactone (GBL), and 1,3-butadiene (Celinska and Grayek, 2009). Methyl ethyl ketone is considered to be an effective liquid-fuel additive and 1,3-butadiene plays important role in the production of synthetic rubber (Kopke et al., 2011).

The production of 2,3-butanediol is known to be from various sugar (or citrate)fermenting microorganisms, including Bacillus amyloliquefaciens, Bacillus subtilis, Enterobacter aerogenes, Klebsiella pneumoniae, Klebsiella oxytoca, Lactococcus lactis, Paenibacillus polymyxa, and Serratia marcescens (Perego et al., 2003; Xiu and Zeng, 2008; Celinsk and Grayek, 2009; Cheng et al., 2010; Jurchescu et al., 2013; Wang et al., 2014). Considering the health concern, these organisms in the group of Enterobacter and Klebsiella species (except for $K$. oxytoca) are categorized as Risk Group 2 (RG2) because of their pathogenicity by the World Health Organization (Celinska and Grajek, 2009).
While Bacillus licheniformis which is potentially the most promising for industrial production of 2,3-BDO belongs to the class of risk 1 (Perego et al., 2003; Jurchescu et al., 2013). To overcome the challenges of using pathogenic organism, bacteria will be isolated from sugarcane bagasse and used for 2,3butanediol production in this research using rice husk. The objective of this work was to investigate the possibility of producing 2,3butainediol from rice husk.

\section{MATERIALS AND METHODS Collection of samples}

Rice husk was collected in a new clean polythene bag from Kalambaina rice mills, Wamakko Local Government Area of Sokoto State. Sugarcane bagasse was collected in a sterile specimen bottle from vegetable market, Sokoto. All the samples were taken to laboratory of Usmanu Danfodiyo University Sokoto.

\section{Composition analysis of the rice husk Extractives}

Approximately $2.5 \mathrm{~g}$ of the rice husk was loaded into a cellulose thimble. With the Soxhlet extractor set up, $150 \mathrm{ml}$ of acetone was used as solvent for extraction. Temperature was carefully adjusted to $70{ }^{\circ} \mathrm{C}$ on the heating mantle for a $4 \mathrm{~h}$ run period. After extraction, the sample was air dried at room temperature. Constant weight of the extracted rice husk was achieved in a convection oven at $105{ }^{\circ} \mathrm{C}$. The $\%(\mathrm{w} / \mathrm{w})$ of the extractives content was calculated using Eq. 1 (Li et al., 2004; and Lin et al., 2010).

$\mathrm{W} 1($ wt. $\%)=\mathrm{Go}-\mathrm{G} 1 / \mathrm{Go} \times 100$

$$
\text { Eq.1 }
$$

Where: $W 1=$ Extractives,

Go $=$ Dry weight of the sample,

$G 1=$ Constant weight of the residues after extraction

\section{Hemicellulose}

One gram (1 g) of extracted dried biomass (G1) was transferred into a $250 \mathrm{~mL}$ Erlenmeyer flask. $150 \mathrm{ml}$ of $0.5 \mathrm{~mol} / \mathrm{dm}^{3}$ $\mathrm{NaOH}$ was added. The mixture was boiled for $3.5 \mathrm{~h}$ with distilled water. It was filtered after cooling and washed until neutral $\mathrm{pH}$. The 
residue was dried to a constant weight at 105 ${ }^{\circ} \mathrm{C}$ in a convection oven (G2). Hemicellulose content $(\% \mathrm{w} / \mathrm{w})$ of rice husk was calculated given Eq. 2 (Li et al., 2004; and Lin et al., 2010; Ayeni et al., 2013).

$$
\begin{array}{r}
W 2(w t . \%)=G 1-G 2 / G o x 100 \\
E q .2
\end{array}
$$

\section{Lignin}

From the extracted rice husk, $0.3 \mathrm{~g}$ (G3) was weighed in glass test tubes and $3 \mathrm{~mL}$ of $72 \% \mathrm{H}_{2} \mathrm{SO}_{4}$ was added. The sample was kept at room temperature for $2 \mathrm{~h}$ with careful shaking at $30 \mathrm{~min}$ intervals to allow for complete hydrolysis. After the initial hydrolysis, $84 \mathrm{~mL}$ of distilled water was added. The second step of hydrolysis was made to occur in an autoclave for 1 hour at $121^{\circ} \mathrm{C}$. The slurry was then allowed to cooled to room temperature. Hydrolysate was filtered. Constant weight of the residues was obtained using conventional oven (G4). Lignin content wt. \% was determined using Eq. 3 bellow (Li et al., 2004; Sluiter et al., 2008).

$\mathrm{W} 3($ wt. \%) = G4(1-W1)/G3 x 100

Eq. 3

\section{Cellulose}

The cellulose content (wt.\%) was calculated by difference, assuming that extractives, hemicellulose, lignin and cellulose are the only components of the entire biomass (Li et al., 2004; Lin et al., 2010).

$\mathrm{W} 4(\mathrm{wt} . \%)=100-(\mathrm{W} 1+\mathrm{W} 2+\mathrm{W} 3)$ Eq. 4

\section{Dilute alkaline pretreatment}

In a 1 Litre capacity conical flask, $50 \mathrm{~g}$ of rice husk was mixed with $500 \mathrm{ml}$ of $2 \%$ $\mathrm{NaOH}$ and shake until it homogenized. The solution was covered with cotton wool and aluminum foil and then allowed to suck for 24hrs. The mixture after $24 \mathrm{hrs}$ was autoclaved at $121{ }^{\circ} \mathrm{C}$ for $15 \mathrm{mins}$ and then allowed to cooled and filtered using Whatman filter paper No1. The residue was washed with distilled water until neutral $\mathrm{pH}$ of 7.0 was obtained and dried (Nikzad et al., 2013).

\section{Hydrolysis of rice husk}

Stock culture of Aspergillus niger was collected from Mycology laboratory of
Usmanu Danfodiyo University Sokoto. It was sub-cultured in a newly prepared SDA and incubated at room temperature for 5 days. Ten grams of the pretreated rice husk was weighed in $250 \mathrm{ml}$ flask and $100 \mathrm{ml}$ of distilled water was added. The flask was covered with cotton wool and aluminium foil and then sterilized at $121{ }^{\circ} \mathrm{C}$ for 15 minutes. The flask was then inoculated with $0.5 \mathrm{ml} \quad\left(1.3 \times 10^{7} \mathrm{cfu} / \mathrm{ml}\right)$ suspension of the Aspergillus niger. The flask was incubated at $37^{\circ} \mathrm{C}$ for 5 days on an orbital shaker, and then the sample was filtered through Whatman filter paper No1. The filterate was then used for determination of reducing sugar and fermentation (Gupta et al., 2009; Negi and Banerjee, 2006).

\section{Determination of reducing sugar}

The reducing sugar content following hydrolysis of the rice husk was determined using the dinitrosalicylic acid (DNS) colorimetric method according to Miller (1959) with glucose as standard. It was assayed by adding $2 \mathrm{ml}$ of 3, 5-DNS reagents to $1 \mathrm{ml}$ of the sample. The mixture was heated in bath for 10 min to develop a red-brown colour. Then $1 \mathrm{ml}$ of $40 \%$ potassium sodium tartrate solutions was added to stabilize the colour, it was then cooled to room temperature. The absorbance of the sample was measured at $540 \mathrm{~nm}$ using ultraviolet (UV-VIS) spectrophotometer. The reducing sugar content was determined by making reference to a standard curve of known glucose (Rabah et al., 2011).

\%Reducing sugar $\left({ }^{\mathrm{mg}} / \mathrm{dl}\right)=$ Abs. of sample/Abs. of Std x Conc. of Std Eq. 5

Keys: Abs. = Absorbance, Std. $=$ Standard, Conc. $=$ Concentration

\section{Fermentation of the hydrolysate Isolation and identification of Clostridium species}

A gram of the sugarcane bagasse was transferred in $10 \mathrm{ml}$ of distilled water and heat shocked in water bath for $10 \mathrm{~min}$ at $70{ }^{\circ} \mathrm{C}$. An aliquot was transferred in to already prepared plate of Nutrient Agar and incubated in an anaerobic incubator at $37{ }^{\circ} \mathrm{C}$. The isolates after $24 \mathrm{hrs}$ were sub cultured based on physical characteristics and incubated. After $24 \mathrm{hrs}$ of 
anaerobic incubation, Gram's staining was carried out to find the morphological characteristics of the isolates. Spore staining technique was employed to determine the organisms' ability to produce spores. Gram positive rod that produced spores was subjected to further biochemical tests for characterization. The tests include: glucose, lactose, sucrose, catalase, indole, $\mathrm{H}_{2} \mathrm{~S}$ motility and urease tests (Owuna et al., 2018; Nata'ala, 2018). PCR and agarose gel electrophoresis were also carried out.

\section{Fermentation}

Fermentation was carried out with Clostridium species according to procedure followed by Owuna et al. (2018) with some modification. The hydrolysate obtained from hydrolysis was used as the fermentation media. Ten milligrams of the hydrolysates were transferred in to $100 \mathrm{ml}$ capacity conical flasks, covered with cotton wool and aluminium foil and autoclaved at $121^{\circ} \mathrm{C}$ for $15 \mathrm{~min}$. and then cooled to room temperature. The $\mathrm{pH}$ of the fermentation medium was adjusted to 6.5 and then $1 \mathrm{ml}$ of prepared suspension of the organism prepared $(0.5 \%$ McFerland Standard) was added in the hydrolysate. The fermentation was allowed to occur in an anaerobic incubator for 3 days with frequent shaking. The fermentation by-product was taken for Gas Chromatography Mass-Spectrophotometer analysis.

\section{Determination of fermentation products}

After the fermentation, the by- products were subjected to analysis using GC-MS to detect and identify the products.

\section{RESULTS}

\section{Structural compositions of the rice husk}

Structural compositions of rice husk were investigated to determine the extractives, hemicellulose, lignin and cellulose. The results (Table 1) shows increase in cellulose and lignin content of the rice husk $32 \%$ to $53.3 \%$ and 8.4 to 30.7 after pretreatment respectively. While extractives and hemicellulose reduces after pretreatment from $29.6 \%$ to $8 \%$ and $30 \%$ to $8 \%$ respectively.

\section{Reducing sugar released after hydrolysis of rice husk using Aspergillus niger}

The results of reducing sugar show increase the amount of sugar daily with the highest production at day 4 . Table 2 shows the results of mean reducing sugar released from hydrolysates with a total of $1.05 \mathrm{~g} / \mathrm{l}$ of sugar. There was significant difference in the daily release of sugar as $\mathrm{P}=0.01(\mathrm{P}<0.05)$.

\section{Isolation and Identification Clostridium species used for fermentation of rice husk}

Basic Microbiological techniques were employed for identification of Clostridium. The macroscopic observations revealed that the colony is white, large, raised and smooth edged. Microscopically, the isolate was found to be purple rod shaped, hence, is Gram positive. The isolate was further subjected to biochemical test for identification. Some of the tests include; spore detection, lactose, glucose, sucrose, catalase, Motility, indole, gas formation, urease, citrate and $\mathrm{H}_{2} \mathrm{~S}$. Table 3 shows the results of characterization and identification of Clostridium.

\section{Molecular biology}

Colony PCR was carried out after series of repeated subcure and obtained a pure culture. The PCR product amplified was run on $1 \%$ agarose gel electrophoresis to visualize the products. Figure 1 shows a product of $1000 \mathrm{bp}$ size.

Analysis of fermentation products using gas chromatography-mass spectroscopy (GCMS)

Characterization of compounds present after fermentation was carried out using Gas Chromatography-Mass Spectroscopy (GCMS). Figure 2 shows various spectra of about 15 compounds which was identified and presented in Table 4. Alcohol 2,3-butanediol $(0.6 \%)$, Furfuryl alcohol $(0.45 \%)$ were found in the fermemtation by-product. 
Table 1: Mean structural compositions of rice husk.

\begin{tabular}{lcc}
\hline Composition & Before pretreatment (\%) & After pretreatment (\%) \\
\hline Extractives & $29.6 \pm 0.05$ & $8.0 \pm 0.06$ \\
Hemicellulose & $30.0 \pm 0.1$ & $8.0 \pm 0.03$ \\
Lignin & $8.4 \pm 0.11$ & $30.7 \pm 0.35$ \\
Cellulose & $32.0 \pm 0.06$ & $53.3 \pm 0.32$ \\
\hline
\end{tabular}

Table 2: Mean Reducing Sugar released from hydrolysates.

\begin{tabular}{lc}
\hline Days & $\mathbf{N a O H}(\mathrm{g} / \mathbf{l})$ \\
\hline 1 & $0.256 \pm 0.004$ \\
2 & $0.2891 \pm 0.001$ \\
3 & $0.2516 \pm 0.003$ \\
4 & $0.2546 \pm 0.002$ \\
\hline
\end{tabular}

Table 3: Biochemical Identification of Clostridium species.

\begin{tabular}{lllllllllllll}
\hline $\begin{array}{l}\text { Biochemical } \\
\text { Test }\end{array}$ & $\mathbf{1}$ & $\mathbf{2}$ & $\mathbf{3}$ & $\mathbf{4}$ & $\mathbf{5}$ & $\mathbf{6}$ & $\mathbf{7}$ & $\mathbf{8}$ & $\mathbf{9}$ & $\mathbf{1 0}$ & $\mathbf{1 1}$ & Isolate \\
\hline Observation & $\begin{array}{l}\text { Gram+ } \\
\text { Rod }\end{array}$ & + & - & + & - & - & - & - & - & weak & - & $\begin{array}{l}\text { Clostridium } \\
\text { spp }\end{array}$ \\
\hline
\end{tabular}

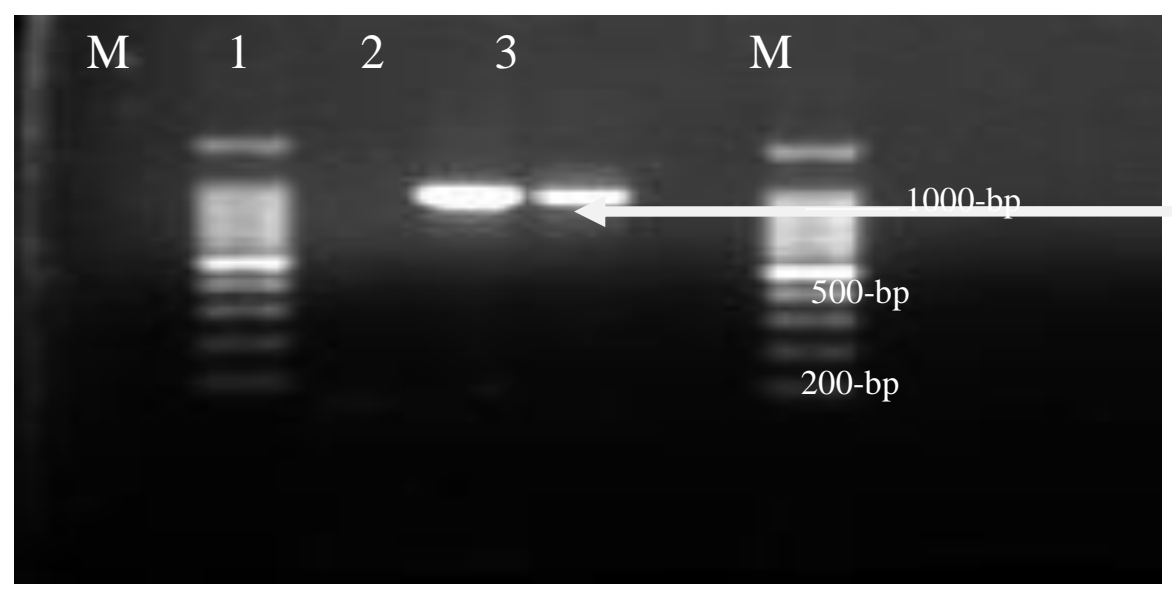

Figure 1: Agarose gel image showing the PCR product amplified from the suspected Clostridium isolate. 


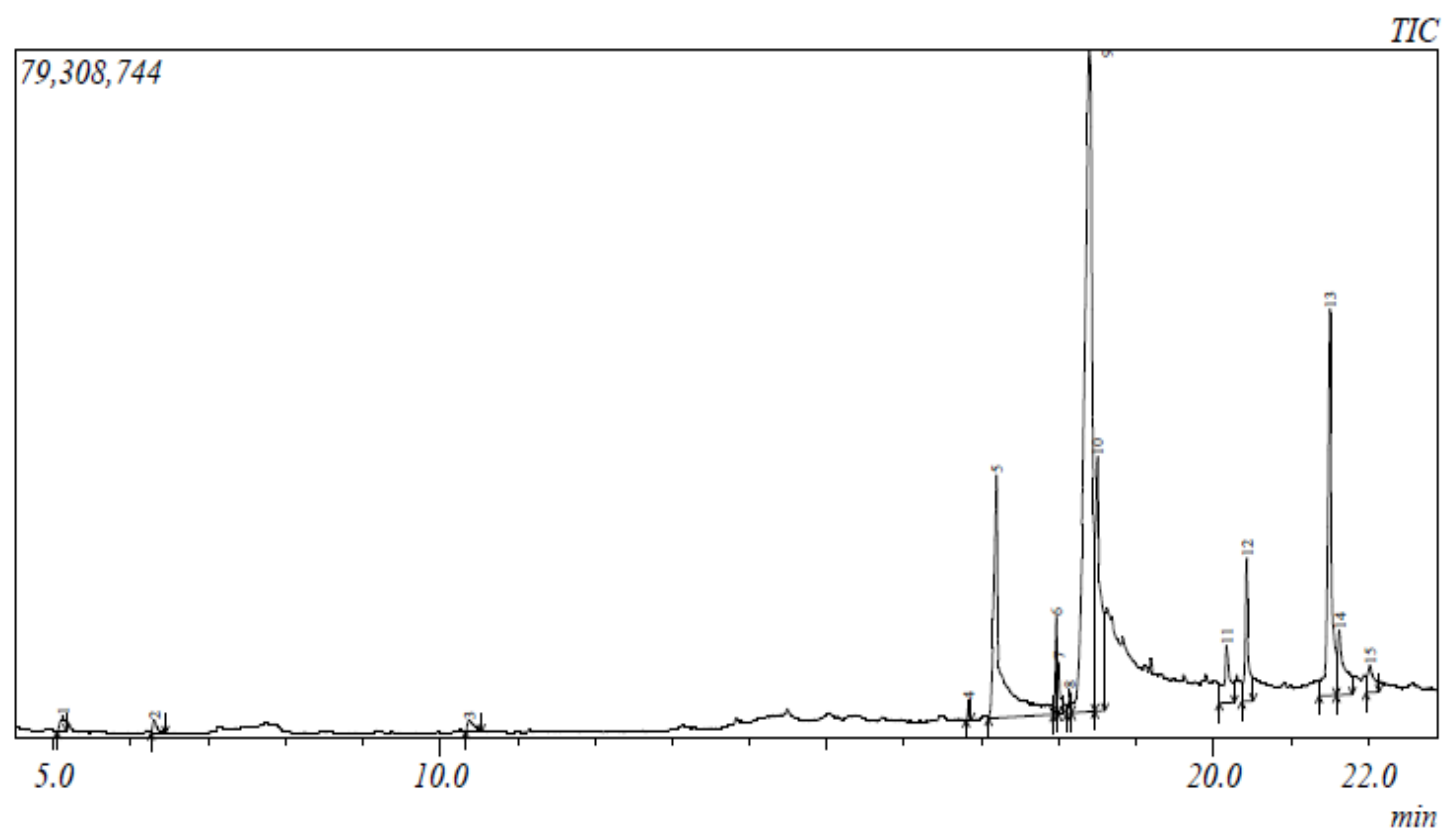

Figure 2: GC Spectrum showing various peaks of the fermentation by-product.

Table 4: Volatile organic compounds identified from the fermentation broth product using GC-MS.

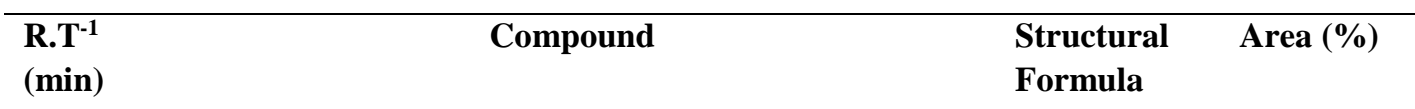

\begin{tabular}{llll}
\hline 5.12 & 2,3-Butanediol & $\mathrm{C}_{4} \mathrm{H}_{10} \mathrm{O}_{2}$ & 0.63 \\
6.30 & 2(3H)-Furanone,5-methyl (Furfuryl alcohol) & $\mathrm{C}_{5} \mathrm{H}_{6} \mathrm{O}_{2}$ & 0.45 \\
10.37 & Thiophene,2-propyl (2-Propylthiophene) & $\mathrm{C}_{7} \mathrm{H}_{10} \mathrm{~S}$ & 0.63 \\
16.83 & Cyclopentanetridecanoic acid, methyl ester & $\mathrm{C}_{19} \mathrm{H}_{36} \mathrm{O}_{2}$ & 0.25 \\
17.19 & n-hexadecanoic acid (palmitic acid) & $\mathrm{C}_{16} \mathrm{H}_{32} \mathrm{O}_{2}$ & 14.73 \\
17.97 & 9,12-Octadecadienoic acid, methyl ester & $\mathrm{C}_{19} \mathrm{H}_{34} \mathrm{O}_{2}$ & 1.34 \\
18.00 & 9-Octadecenoic acid (Z)-, methyl ester & $\mathrm{C}_{19} \mathrm{H}_{36} \mathrm{O}_{2}$ & 1.04 \\
18.14 & Unknown & $\mathrm{C}_{25} \mathrm{H}_{42} \mathrm{O}_{2}$ & 0.49 \\
19.18 & 17-Octadecynoic acid & $\mathrm{C}_{18} \mathrm{H}_{32} \mathrm{O}_{2}$ & 10.69 \\
20.17 & 9,12-Octadecadienoic acid (Z,Z)- & $\mathrm{C}_{18} \mathrm{H}_{32} \mathrm{O}_{2}$ & 47.26 \\
20.42 & Hexadecanoic acid, 2-hydroxy-1-(hydroxylmethyl)ethyl & $\mathrm{C}_{19} \mathrm{H}_{38} \mathrm{O}_{4}$ & 4.06 \\
& ester & & \\
21.50 & (R)-(-)-14-methyl-8-hexadecyn-1-ol & $\mathrm{C}_{17} \mathrm{H}_{32} \mathrm{O}$ & 13.17 \\
21.62 & 13-Tetradecenal & $\mathrm{C}_{14} \mathrm{H}_{26} \mathrm{O}$ & 3.66 \\
22.02 & Z,Z-3,13-Octadecedien-1-ol & $\mathrm{C}_{18} \mathrm{H}_{34} \mathrm{O}$ & 1.61 \\
\hline
\end{tabular}




\section{DISCUSSION}

The result of the structural composition of rice husk shows a high proportion of cellulose accounting for about $32 \%$ and $53.3 \%$ before and after pretreatment, respectively (Table 1). This might be attributed to the fact that rice is herbaceous plant known to have less rigid cell wall as such is expected to have more cellulose content. Sticlen (2007) reported that lignocellulosic biomass contains about $30 \%$ to $50 \%$ cellulose, for which rice husk is characterized as one of the lignocellulosic biomass. This is similar with the studies by Noha (2015) who reported a cellulose content of $31.01 \%, 32.23 \%, 30.80 \%$ and $33.65 \%$ from rice straw collected from Egypt, Murcia, Valencia and Andalusia respectively. The study also showed similarity with finding of Anwar et al. (2017) who reported a cellulose content of rice husk of $32.67 \%$ in their study. Adamafio et al. (2009) reported decrease in lignin, cellulose and hemicelluloses in their work. Increase in the cellulose content of rice husk was observed after pretreatment. This implies that cellulose was released from the compacted structures after pretreatment. The finding implies that rice husk contained substantial sugar that can be converted to product such as alcohols or biofuels.

Hemicelluloses content of rice husk in this research work was found to be $30 \%$ and $8 \%$ before and after pretreatment, respectively. The result falls within the range (5\% to $30 \%$ ) of hemicellulose content reported for lignocellulosic biomass (Jie, 2004). The result of this work differs from the values of $26.47 \%$, $25.26 \%, 24.79 \%$ and $26.68 \%$ previously reported for rice straw collected from Egypt, Murcia, Valencia and Andalusia respectively (Noha, 2015). However, the study shows similar finding of Williams and Nugranad (2000), who reported a hemicelluloses content of $29.3 \%$ from rice husk in their work. When compared with the hemicelluloses content of $11.96 \%$ and $17.7 \%$ reported by Saha et al. (2005) and Park et al. (2004) respectively, the reported content of this work revealed higher value, which might be as a result of difference in geographic location, methods of harvesting or processing methods. The finding implies that rice husk is a good substrate for biofuel production and other valuable alcohols.

The lignin content found in this research work was found to lower with the value of $8.4 \%$. The result is lower than the value (18.81\%) reported by Anwar et al. (2004) who conducted their research using rice husk in Indonesia. Moreover, another study on rice husk by Noha (2015) at Egypt shows higher content of lignin compared the value found in this work. The finding implies that rice husk could be easily hydrolyzed and produces valuable compounds.

Extractives account for about $29.6 \%$ and are mainly a group of cell wall chemicals comprising fats, fatty acids, phenols and many other organic compounds. Extractives are nonstructural components of plant cell walls responsible for colour, smell and durability (Rowell, 2012). The value of extractives in this work is higher compared to the value (11\%) reported by Mansor et al. (2019) from Pineapple leaves. The results is also higher than the values found in sugar cane bagasse and Shea tree sawdust reported by Ayeni et al. (2015) which account for $2.14 \%$ and $1.9 \%$, respectively. The differences in the values of extractives might be attributed to the difference in the biomass substrates.

After pretreatment, it was observed that the composition of rice husk differs. There was decrease in the amount of extractives, increase in the cellulose content, increase in lignin content and decrease in the content of hemicellulose. The result implies that, the lignin barrier in the rice husk was removed, hemicellulose was also removed and cellulose was released to be accessible by hydrolytic organism.

Reducing sugar was determined daily during hydrolysis with Aspergillus niger to determine the amount of reducing sugar released. The hydrolysis was carried out for a period of 5 days. The analysis of sugar was 
started at day 2 to allow for acclimatization of organism in the substrate. The results showed increase in the amount of sugars released across the days with peak release at day 4 . This might be attributed to the fact that $\mathrm{NaOH}$ have the ability to attack lignin in biomass to make cellulose readily available for hydrolytic organism. There was significant difference in the daily release of sugar as $\mathrm{P}=0.01(\mathrm{P}<0.05)$. Adejimo et al. (2019) reported similar results of peak release of sugar at $79^{\text {th }}$ hour (day 4). The variation of sugar released across the days is similar with the work by Nata'ala (2018) who reported highest concentration in $5^{\text {th }}$ day and lowest concentration in $2^{\text {nd }}$ day. The result implies that Aspergillus niger used in the hydrolysis produced extracellular enzymes that hydrolyzed the cellulose in the rice husk.

Fermentation by-product was analyzed using Gas Chromatography Massspectrometry. A close examination of the Spectra from the chromatogram on mass spectrometry revealed that the compounds include alcohols, fatty acids, fatty aldehydes and thiopene with fatty acids as the major compounds. The alcohol 2,3-butanediol $(0.6 \%)$, Furfuryl alcohol $(0.45 \%)$ were found in the fermemtation by-product. The 2,3butanediol was formed from the microbial fermentation of sugar in the substrate. Glucose which is hexose sugar (cellulose) and Xylose which is pentose sugar (hemicelluloses) was fermented to produce 2,3-butanediol as previously reported (Wang et al., 2010). 2,3butanediol is a precursor compound for the production of 2-butanol during anaerobic fermentation of sugar, 1,3-butadiene and methyl Ethyl Ketone (Hannes et al., 2019; Koutins et al., 2014). Moreover, the compound is a promising alcohol that itself can be use as liquid fuel. It has other uses in foods industry, cosmetics and pharmaceutical industry. Furfuryl alcohol (2(3H)-furanone, 5-methyl) is also an alcohol produced from the fermentation of rice husk. The compound was known to be a product from biocatalytic reduction of furfural which could be produced by microbial conversion of pentosan, a pentose sugar from hemicellulose of rice husk substrate as reported from another research (Xue-Ying et al., 2019; Elisandra et al., 2019). The compound has been in use by foods industries, pharmaceutical industries as fragrance agent as well as in the production of other valuable chemicals such as ethyl furfuryl ether, tetrahydrofurfuryl alcohol (Maris et al., 2016). The results imply that rice husk can be fermented in an anaerobic condition to produce alcohols.

Fatty acids which are the major compounds identified from the fermentation products ranges from $\mathrm{C}_{16}$ to $\mathrm{C}_{25}$ compounds with 9,12-Octadecanoic acid as the major fatty acid found in the fermentation product. The fatty acids might have come from the fermentative organism as fatty acids are constituent of microbial cell wall. Another source of fatty acids could be the rice husk because rice was known to contain oil as previously reported (Fajriyat et al., 2017; XinPing et al., 2015). Fatty acids are also known as important compounds to play role as antioxidants, antimicrobial and antiinflammatory agents (Zubair et al., 2013). The result implies that rice husk contains essential oil that can be exploited and use in various forms such as biodiesel, foods industries, pharmaceutical industries, perfumes and aromatherapy.

\section{Conclusion}

At the end of this research, rice husk was found to have contained lignin $(8.4 \%)$, cellulose $(32 \%)$ and hemicelluce $(30 \%)$ before pretreatment and lignin $(30.7 \%)$, cellulose (53.3\%) and hemicelluce $(8.0 \%)$ after pretreatment. A total amount of sugar released was $1.05 \mathrm{~g} / \mathrm{l}$ from the rice husk. Rice husk was also found to contain fatty acids that can be exploited in the production of biodiesel. The fatty acids play vital role in bioenergy sector, foods and pharmaceutical industries. This research showed that rice husk has potential in the production of alcohols that can be used as 
biofuel and may reduce the burden of fossil fuels.

\section{COMPETING INTERESTS}

The authors declare that they have no competing interests.

\section{AUTHORS' CONTRUBUTIONS}

AAF and ADI brought the idea of the study. AS, AAF, AYB and ADI design the experiment. AS and AYB, AYB helped with related literatures and reviewed the write-up. AS conducted the lab experiment. AS, ADI, MHU and IM analysed the results. All the authors contributed equally in writing and reviewing the manuscript.

\section{ACKNOWLEDGMENTS}

The authors acknowledged the help of Sabi'u Muhammad during the laboratory work.

\section{REFERENCES}

Adejimo AL, Agboola FK, Layokun SK. 2009. Hydrolysis of maize starch using amylolytic enzymes extracted from sorgum malt. Int. J. Biol. Chem. Sci., 3(5): 1030-1041.

DOI: http://dx.doi.org/10.4314/ijbcs.v3i5.51082

Adamafio NA, Obodai M, Brimpong B. 2009. Solid state fermentation of maize (zea mays) cob by Pleurotus ostreatus strain EM-1: Biopolymer profile and cellulose degradability. Int. J. Biol. Chem. Sci. 3(6): $1459-1466 . \quad$ DOI: http://dx.doi.org/10.4314/ijbcs.v3i6.53169

Anwar M, Bambang P, Nita A. 2017. Lignin Isolation Process from Rice Husk by Alkaline Hydrogen Peroxide: Lignin and Silica Extracted. International on Chemistry, Chemical Process and Engineering. AIP Conference Proceedings 1823: 020013-1-0200135. DOI: http://dx.doi.org/10.1063/1.4978086

Ayeni AO, Hymore FK, Mudliar SN, Deskmukh SC, Satpute DB, Omoleye JA Pandey RA. 2013. Hydrogen peroxide and lime based oxidative pretreatment of wood waste to enhance enzymatic hydrolysis for a biorefinery: process parameters optimization using response surface methodology. Journal of Fuel, 106: 187-194. DOI: https://doi.org/10.1016/j.fuel.2012.12.078

Ayeni AO, Adeeyo OA, Oyinlola MO, Temitayo EO. 2015. Compositional Analysis of Lignocellulosic Materials: Evaluation of an Economically Viable Method Suitable for Woody and Non-Woody Biomass. American Journal of Engineering Research, 4(4): 14-19. www.ajer.org

Celinska E, Grayek W. 2009. Biotechnological production of 2,3- butanediol: Current state and prospects. Journal of Biotechnology, 27: 715-725. DOI: 10.1016/j.biotechadv.2009.05.002

Cheng KK, Liu Q, Zhang JA, Li JP, Xu JM, Wang GH. 2010. Improved 2,3butanediol production from corncob acid hydrolysate by fed-batch fermentation using Klebsiella oxytoca. Journal of Process Biochemicals, 45(4): 613-616. DOI: https://doi.org/10.1016/j.procbio.2009.12 .009

Elisandra S, Rambo MKD, Vianai CGC, Marasca N, Lacerda GE, Rambo MCD, Fernandes RMN. 2019. Sustainable Production of Furfural and 5hidroximetilfurfural from Rice Husks and Soybean Peel by Using Ionic Liquid. Food Science and Technology, 5: 342355.

DOI: http://dx.doi.org/10.1590/fst.04419

Fajriyat M, Meta M, Amran L, Zainal Z. 2017. Components, Fatty Acid and Mineral Composition of Rice Bran Oil Extracted By Multistage With Hexane and Ethanol. International Journal of Scientific and Technology Research, 6(11): 63-69. www.ijstr.org

Gupta R, Sharma KK, Kuhad RC. 2009. Simultaneous saccharification and 
fermentation of Prosopis jutiflora, a woody substrate, for the production of cellulosic ethanol by Saccharomyces cerevisiae and Pichia stipitis- NCIM 3498. Journal of Bioresouce. Technology, 100: 12141220.

Hannes R, Hans M, Michael S. 2019. Microbial 2-butanol production with Lactobacillus diolivorans. Journal of Biotecnology for Biofuel, 12(262). DOI: https://doi.org/10.1186/s13068-0191594-5

Hatti-Kaul R, Tornvall U, Gustafsson L, Borjesson P. 2007. Industrial biotechnology for the production of biobased chemicals-a cradle-to-grave perspective. Journal of Trends in Biotechnology, 259(3): 119-124. DOI: 10.1016/j.tibtech.2007.01.001

Ji X J, Nie ZK, Huang H, Ren LJ, Peng C. Ouyang PK. 2011. Elimination of carbon catabolite repression in Klebsiella oxytoca for efficient 2,3-butanediol production from glucose- xylose mixtures. Journal of Applied Microbiology and Biotechnology, 89(4): 1119-1125. DOI: 10.1007/s00253-0102940-5

Jie DMS. 2014. Butanol Production from Lignocellulosic Biomass and Agriculture Residues by Acetone-Butanol-Ethanol Fermentation. PhD thesis, Ohio State University, Ohio, p. 210-255.

Jurchescu IM, Hamann J, Zhou X, Ortmann T, Kuenz A, Prube U, Lang S. 2013. Enhanced 2,3-butanediol production in fed-batch cultures of free and immobilized Bacillus licheniformis DSM 8785. Journal of Applied Microbiology and Biotechnology, 97(15): 6715-6723. DOI: 10.1007/s00253-013-4981-z.

Kopke M, Christophe M, FungMin L, Joseph HT, Mohammed SA, Joshua JC, Bakir A, Sean DS. 2011. 2,3-Butanediol Production by Acetogenic Bacteria, an Alternative Route to Chemical Synthesis,
Using Industrial Waste Gas. Journal of Applied and Environmental Microbiology, 77(15): 5467-5475. DOI: 10.1128/AEM.00355-11

Koutinas AA, Vlysidis A, Pleissner D, Kopsahelis N, Garcia IL, Kookos IK, Papanikolaou S, Kwanb TH, Lin CSK. 2014. Microbial Valorization of industrial waste and by-product streams via fermentation for the production of chemicals and biopolymers. Journal of Chemical society, 43: 2587-2627. DOI: https://doi.org/10.1039/C3CS60293A

Li S, Xu S, Liu S, Yang C, Lu Q. 2004. Fast pyrolysis of biomass in free-fall reactor for hydrogen-rich gas. Fuel Process Technology, 85: 1201-1211. DOI: 10.1016/j.fuproc.2003.11.043

Lin L, Yan R, Liu Y, Jiang W. 2010. In-depth investigation of enzymatic hydrolysis of biomass wastes based on three major components: cellulose, hemicellulose, and lignin. Bioresource Technology, 101(21): 8217-8223. DOI: 10.1016/j.biortech.2010.05.084

Mansor AM, Lim JS, Ani FN, Hashim H, Ho WS. 2019. Characteristics of Cellulose, Hemicellulose and Lignin of MD2 Pineapple Biomass. Chemical Engineering Transactions, $\mathbf{7 2 :}$ 79-84. DOI: https://doi.org/10.3303/CET1972014

Mariscal R, Maireles-Torres P, Ojeda M, Sadaba I, Lopez Granados M. 2016. Furfural: A renewable and versatile platform molecule for the synthesis of chemicals and fuels. Journal of Energy and Environmental Science, 9(4): 11441189.

DOI: https://doi.org/10.1039/C5EE02666K

Miller GL. 1959. Use of dinitrosalicylic acid reagent for determination of reducing. Journal of Analytical Chemistry, 31(3): 426-428.

DOI: https://doi.org/10.1021/ac60147a030

Nata'ala KM. 2018. Studies on the Potentials of Using Cyperrus esculentus $L$. 
(Tigernut) Residues for Bioethanol Production. M.Sc Dissertation, Usmanu Danfodiyo University, Sokoto, Nigeria. p. 84-93.

Negi S, Banerjee R. 2006. Optimization of Amylase and Protease Production from Aspergillus awamori in Single Bioreactor Through EVOP Factorial Design Technique. Journal of Food Technology and Biotechnology, 44(2): 257-261.

Nikzad M, Movagharnejad K, Najafpour GD, Talebnia F. 2013. Comparative studies on effect of pretreatment of rice husk for enzymatic digestibility and Bioethanol production. International Journal of Engineering, 26(5): 455-464.

Nilegaonkar S, Bhosale SB, Kshirsagar DC, Kapadi AH. 1992. Production of 2,3butanediol from glucose by Bacillus licheniformis. World Journal of Microbiology and Biotechnology, 8: 378381. DOI: 10.1007/BF01198748

Noha SE. 2015. Utilization of Energy from Residual Biomass of Rice Husk in Egypt. $\mathrm{PhD}$ thesis, University of Granada, Granada. P 21-56.

Owuna G, Makut MD, Ekeleme IK, Obiekezie SO. 2018. Isolation, Identification and Production of Biobutanol by Different Clostridium species Isolated from Soil Using Waste Paper and Sugar Cane Molasses. South Asian Journal of Research in Microbiology, 2(1): 1-9. DOI:

https://doi.org/10.9734/sajrm/2018/v2i12 9237

Oyeleke SB, Manga SB. 2008. Essentials of Laboratory Practical in Microbiology $\left(1^{\text {st }}\right.$ edn). Tolbest Publishers: Minna, Nigeria. 36-67.

Park EY, Anah PN, Okuda N. 2004. Bioconversion of waste office paper to L(+)-lactic acid by the filamentous fungus Rhizopus oryzae, Journal of Bioresource Technology, 93(1): 77-83. DOI: 10.1016/j.biortech.2003.08.017
Perego P, Converti A, Del BM. 2003. Effects of temperature, inoculum size and starch hydrolyzate concentration on butanediol production by Bacillus licheniformis. Journal of Bioresource and Technology, 89(2): 125-131. DOI: $10.1016 / \mathrm{s} 0960-$ 8524(03)00063-4

Rabah AB, Oyeleke SB, Manga SB, Hassan LG. 2011. Utilization of millet and guinea corn husks for Bioethanol production. African Journal Microbiological Resource, $\quad \mathbf{5}(31)$ : 5721-5724. DOI: https://doi.org/10.5897/AJMR11.1127

Ragauskas AJ, Williams CK, Davison BH, Britovsek G, Cairney J, Eckert CA. 2006. The path forward for biofuels and biomaterials. Journal of Science, 311(5760): $\quad$ 484-98. DOI: $10.1126 /$ science. 1114736

Rowell RM. 2012, Handbook of wood chemistry and wood composites. CRC press, Boca Raton, Florida, USA.

Saha BC, Iten LB, Cotta MA, Wu YV. 2005. Dilute Acid Pretreatment, Enzymatic Saccharification and Fermentation of Wheat Straw to Ethanol. Journal of Process Biochemistry, 40(12): 36933700.

DOI: https://doi.org/10.1016/j.procbio.2005.04 .006

Sluiter A, Hames B, Ruiz R, Scarlata C, Sluiter J, Templeton D. Crocker D. 2008. Determination of Structural Carbohydrates and Lignin in Biomass, Colorado, Laboratory. Analytical Procedure.

Sticlen MB. 2007. Feedstock Crop Genetic Engineering for Alcohol fuels. Journal of Crop Science, 47(6): 2238-2248. DOI: https://doi.org/10.2135/cropsci2007.04.0 212

Syu MJ. 2001. Biological production of 2,3butanediol. Journal of Applied Microbiology and Biotechnology, 55(1): 10-18. DOI: $10.1007 / \mathrm{s} 002530000486$ 
Wang A, Wang Y, Jiang T, Li L, Ma C, Xu P. 2010. Production of 2,3-butanediol from corncob molasses, a waste by-product in xylitol production. Journal of Applied Microbiology and Biotechnology, 87(3): 965-970. DOI: $10.1007 /$ s00253-0102557-8

Williams PT, Nugranad N. 2000. Comparison of products from the pyrolysis and catalytic pyrolysis of rice husks. Journal of Energy, 25(6): 493-513. DOI: https://doi.org/10.1016/S03605442(00)00009-8

Wu KJ, Saratale GD, Lo YC, Chen WM, Tseng ZJ, Chang MC. 2008. Simultaneous production of 2,3-butanediol, ethanol and hydrogen with a Klebsiella sp. Strain isolated from sewage sludge. Bioresource Technology, 99(5): 7966- 7970. DOI: 10.1016/j.biortech.2008.03.062

Xin-Ping X, Xiao-Dong Z, Lei C, Lai-Zhi S, Hong-Yu S. 2015. Characterization of Rice Husk by Pyrolysis-Gas Chromatography-Mass Spectrometry.
Journal of Instrumentation Science and Technology, 43(1): 65-73. DOI: 10.1080/10739149.2014.961643

Xiu ZL, Zeng AP. 2008. Present state and perspective of downstream processing of biologically produced 1,3-propanediol and 2,3-butanediol. Journal of Applied Microbiology and Biotechnology, 78(6): 917-926. DOI: 10.1007/s00253-008$1387-4$

Xue-Ying Z, Zhong-Hua X, Min-Hua Z, Chuan-Fu W, Ning L. 2019. Selective Synthesis of Furfuryl Alcohol from Biomass-Derived Furfural Using Immobilized Yeast Cells. Journal of Chemical Catalysts, 9(1): 61-70. DOI: $10.3390 /$ catal9010070

Zubair M, Hassan S, Rizwan K, Rasool N, Riaz M, Zia-Ul-Haq M, Vincenzo, DF. 2013. Antioxidant Potential and Oil Composition of Callistemon viminalis Leaves. The Scientific World Journal, $\quad 7$ : $1-8 . \quad$ DOI: http://dx.doi.org/10.1155/2013/489071 